\title{
Response of Shami goats and kids to variable levels of soyabean or sunflower oils in diets
}

\author{
H.H. Titi ${ }^{1,3}$, Y.L. Hasan ${ }^{1}$, K. Al-Ismail ${ }^{1}$, H. Zakaria ${ }^{1}$, M.J. Tabbaa ${ }^{1}$, \\ A.Y. Abdullah ${ }^{2}$ and B.S. Obeidat ${ }^{2}$
}

\author{
${ }^{1}$ University of Jordan, Department of Animal Production, Faculty of Agriculture \\ Amman 11942, Jordan \\ ${ }^{2}$ Jordan University of Science \& Technology, Department of Animal Production, Faculty of Agriculture \\ Irbid 22110, Jordan
}

(Received 28 March 2011; revised version 25 August 2011; accepted 6 December 2011)

\begin{abstract}
A study was conducted to determine the effect of feeding soyabean or sunflower oil to lactating Shami goats on milk production, composition and fatty acid profile. Goats $(n=125)$, 2 to 4 years of age and 55 to $60 \mathrm{~kg}$ liveweight, were randomly assigned to 5 treatment groups ( 25 each) in a completely randomized design. Diets were: a control ration (C), control supplemented with $3 \%$ soyabean oil $(3 \% \mathrm{SBO})$, control supplemented with $5 \% \mathrm{SBO}$, control supplemented with $3 \%$ sunflower oil ( $3 \% \mathrm{SFO})$, and a control supplemented with $5 \%$ SFO. Variables measured were milk production, milk composition, dry matter intake, body weight, weaning weight of kids, blood metabolites, and milk and blood fatty acid profiles. Daily milk production was reduced $(\mathrm{P}<0.05)$ in most treatments. Fat and protein yields were maximum $(\mathrm{P}<0.05)$ at $3 \% \mathrm{SBO}$ while energy corrected milk was highest $(\mathrm{P}<0.05)$ for the $3 \% \mathrm{SBO}$. Feed intake was least $(\mathrm{P}<0.05)$ for the $3 \% \mathrm{SFO}$ group and feed to milk ratio was highest $(\mathrm{P}<0.05)$ for the $3 \% \mathrm{SBO}$ group. Values for the serum cholesterol were highest $(\mathrm{P}<0.05)$ for the SBO kids. Meanwhile, triglycerides were reduced $(\mathrm{P}<0.05)$ following oil treatment with the lowest $(\mathrm{P}<0.05)$ value in the serum of the $5 \% \mathrm{SBO}$ kids. Total conjugated linoliec acid (CLA) content in milk was mostly increased $(\mathrm{P}<0.05)$ for oil treated goats. In the blood of kids, total CLA was maximum $(\mathrm{P}<0.05)$ for kids of the $5 \% \mathrm{SFO}$ group.

Results indicate that supplementing lactating goat diet with either oils did not improve milk production, milk composition, or growth rate and weaning weight of their kids, but improved their energy corrected milk and CLA content. However, only SBO increased cholesterol level in the blood in kids.
\end{abstract}

KEY WORDS: goat, kids, soyabean oil, sunflower oil, milk production, milk composition, fatty acid profile, CLA

\footnotetext{
${ }^{3}$ Corresponding author: e-mail: htiti@ju.edu.jo
} 


\section{INTRODUCTION}

Goat milk has been identified as an alternative for infants and adults who are either sensitive or allergic to cow's milk. The nutritional advantage of goat milk has been attributed to the small size of fat globules making the product more easily digestible (Mir et al., 1999). Fat of such milk contains high level of saturated fatty acids ( $65 \%$ of total fatty acids), particularly palmitic acid, which has hypercholesterolaemic properties (Zhang et al., 2006).

On the other hand, it has been shown recently that food products from ruminants are the richest natural sources of conjugated linoleic acid (CLA) (Mir et al., 1999). Conjugated linoleic acid refers to a group of 18 carbon conjugated fatty acids (AbuGhazaleh et al., 2002). The current upsurge of interest in CLA started after the discovery that it is associated with anticarcinogenic activity, immunomodulating, lean body mass enhancing and antidiabetic properties (Zhang et al., 2006). AbuGhazaleh et al. (2002) reported that CLA had strong antioxidative effects and proposed this as possible explanation for anticarcinogenic properties.

The concentration of CLA could be increased by supplementing ruminant diets with polyunsaturated fatty acids sources such as vegetable oils or processed oil seeds, or by increasing the forage concentration in the diet (Zhang et al., 2006). Bernal-Santos et al. (2003) showed that vegetable oils rich in linoleic acid, like soyabean oil, have been seen to increase milk fat percentage and CLA content in milk fat in ruminants. Likewise, Loor et al. (2002) found that feeding canola oil to lactating Holstein cows increased the concentration of CLA in the milk. Supplementing goat diet with 3\% different vegetable oils (canola, sunflower or soyabean oil) showed an increase in CLA concentration in Saanen goat milk (Matsushita et al., 2007).

Increasing the CLA content and changing the fatty acids profile in milk by dietary manipulation may provide a value-added to feed (Mir et al., 1999). However, differences in response may be linked to animal characteristics like species and/ or breed (Chilliard et al., 2003). Previous work with dietary oil supplementation concentrated on milk production and composition with no interest of the energy value of this milk or the impact on animals suckling this milk. Moreover, fewer trials and less information are available on the fat supplementation for ewes and goats than for dairy cows (Chilliard et al., 2003).

Therefore, the objective of this study was to study the effect of supplementing two different oils: soyabean oil or sunflower oil, to the diet of lactating Shami goats on milk production, composition, and fatty acid profile and CLA content, as well as on growth of their kids. 


\section{MATERIAL AND METHODS}

\section{Animals and diets}

A total of one hundred and twenty five lactating Shami goats with initial body weight ranged from 55 to $60 \pm 1.36 \mathrm{~kg}$ and 2 to 4 years old were used in this study. The experiment was commenced immediately after kidding and lasted for 60 days of lactation. All goats had given birth at least once before being used in the experiment. Goats were weighed once at the beginning of the experiment and once at the end of experiment. Goats were randomly assigned into one of 5 dietary treatment groups in a completely randomized design. Diets utilized were total mixed ration (TMR) that included: control ration with no supplement (C), control ration supplemented with 3\% soyabean oil (SBO; 3\%SBO), control ration supplemented with $5 \% \mathrm{SBO}$, control ration supplemented with $3 \%$ sunflower oil (SFO; 3\%SFO), and a control ration supplemented with 5\%SFO. The percent ingredient composition of each ration is shown in Table 1. Diets were formulated to be about isonitrogenous but not isocaloric.

Table 1. Ingredient composition and chemical composition of the experimental diets

\begin{tabular}{|c|c|c|c|c|c|}
\hline \multirow{2}{*}{ Item } & \multicolumn{5}{|c|}{ Diets } \\
\hline & control & $3 \% \mathrm{SBO}$ & $5 \% \mathrm{SBO}$ & $3 \%$ SFO & $5 \% \mathrm{SFO}$ \\
\hline \multicolumn{6}{|l|}{ Ingredients } \\
\hline barley & 60 & 60 & 60 & 60 & 60 \\
\hline soyabean meal (44\%) & 13 & 13 & 13 & 13 & 13 \\
\hline lucerne hay & 10 & 10 & 10 & 10 & 10 \\
\hline straw & 5 & 5 & 5 & 5 & 5 \\
\hline wheat bran & 10 & 10 & 10 & 10 & 10 \\
\hline oil & 0 & 1.8 & 3 & 1.8 & 3 \\
\hline dicalcium phosphate & 1 & 1 & 1 & 1 & 1 \\
\hline salt & 0.4 & 0.4 & 0.4 & 0.4 & 0.4 \\
\hline limestone & 0.5 & 0.5 & 0.5 & 0.5 & 0.5 \\
\hline mineral and vitamin $\operatorname{mix}^{*}$ & 0.1 & 0.1 & 0.1 & 0.1 & 0.1 \\
\hline \multicolumn{6}{|l|}{ Chemical composition $^{2}$} \\
\hline dry matter, \% & 87.9 & 88.5 & 88.5 & 88.5 & 88.8 \\
\hline crude protein, \% & 16.3 & 15.8 & 15.9 & 16.1 & 16.0 \\
\hline ether extract, \% & 2.7 & 4.3 & 5.4 & 4.2 & 5.5 \\
\hline NDF, $\%$ & 38.5 & 42.5 & 39.3 & 38.1 & 41.2 \\
\hline ADF, \% & 8.6 & 8.3 & 9.1 & 8.3 & 8.7 \\
\hline ASH, \% & 6.5 & 7.5 & 6.1 & 5.5 & 6.4 \\
\hline $\mathrm{ME}^{3}, \mathrm{MJ} \backslash \mathrm{kg}$ & 10.59 & 11.11 & 11.62 & 11.10 & 11.63 \\
\hline \multicolumn{6}{|c|}{$\begin{array}{l}\text { vita-M premix (DADvet, Na'ur, Jordan) each } 1 \text { g contains: IU: vit. A } 1500 \text {; vit. } \mathrm{D}_{3} 150 \text {; mg: } \\
\text { vit. } \mathrm{E}_{2} 50 \% \text {; } \mathrm{CaCO}_{3} 1 ; \mu \text { g: vit. } \mathrm{B}_{1} 300 \text {; vit. } \mathrm{B}_{2} 300 \text {; vit. } \mathrm{B}_{6} 300 \text {; vit. } \mathrm{K}_{3} 50 \% 300 \text {; manganese } \\
\text { oxide } 218 \text {; ferrous sulphate } 435 \text {; cupper oxide } 15.5 \text {; zinc oxide } 138.5 \text {; potassium iodide } 2.2 \text {; } \\
\text { sodium selinate } 0.9 \text {; cobalt carbonate } 0.43{ }^{2} \text { all results are expressed based on dry matter basis } \\
3 \text { ME - calculated using NRC (1985); values ME for oil was calculated as } 1 \text { g of oil = } 9 \text { kcal }\end{array}$} \\
\hline
\end{tabular}


Percentage of supplemented oil in the diet was calculated as a percent of barley content in the ration.

Goats were kept $(1 \times 1.5 \mathrm{~m} /$ head $)$ and fed individually at a level of $1.5 \mathrm{~kg} \mathrm{DM}$ per head per day from the TMR. In addition, they had ad libtum access to lucerne hay and amount consumed was measured daily as the difference between offered and left at the next day. Rations were mixed twice weekly and daily allowances were offered for all animals once at 7.00 a.m. Clean drinking water was provided all the time. Animals were maintained at ambient temperature and natural day length in covered-seal yards with an open side.

\section{Feed sampling and analysis}

Diets were sampled just after mixing and kept frozen for chemical analysis. Samples were ground through a 1-mm screen by IKA mill (Germany) and analysed for dry matter (DM), crude protein (CP), ether extract (EE) and ash (AOAC, 1995). Neutral detergent fibre (NDF) and acid detergent fibre (ADF) were analysed according to Georing and Van Soest (1970). The chemical composition of the experimental diets is shown in Table 1.

\section{Milk and blood sampling}

Milk production was measured individually once weekly and adjusted for one week production. A double oxytocin injection procedure was used to estimate milk production over a $4 \mathrm{~h}$ period. Kids were separated from their dams $3 \mathrm{~h}$ prior to the first injection. Milk samples were preserved with 2-3 $\mathrm{ml}$ potasium permanganate and stored in the freezer untill analysis. Kids of all groups were weighed at parturition and left with their dams in the same yard till weaning. Weaning weights were measured, and weight gain and milk conversion ratio were calculated.

Blood samples $(10 \mathrm{ml})$ were obtained at the $6^{\text {th }}$ and $8^{\text {th }}$ week from the jugular vein of each kid in each treatment into heparinized tubes and centrifuged at $3000 \mathrm{~g}$ for $15 \mathrm{~min}$ for harvesting plasma. Plasma was frozen until fat separation and fatty acid analysis. Serum cholesterol and triglycerides were determined using automated enzymatic procedure (Merck-Mexico and IA for cholesterol and triglyceride, respectively) (Espinoza et al., 1997).

\section{Milk composition}

Milk samples were analysed for fat (Gerber method), crude protein $(\mathrm{N} \times 6.38)$ and total solids content using standard procedures of AOAC (1995). 
Energy corrected milk (ECM) was calculated following the equation of AbuGhazaleh et al. (2002):

$\mathrm{ECM}=(0.3246 \times$ milk yield $)+(12.86 \times$ fat yield $)+(7.04 \times$ protein yield $)$

Milk energy value (MEV) was also calculated according to the equation given by Baldi et al. (2002):

$$
\mathrm{MEV}=203.8+(8.36 \times \text { fat } \%)+(6.29 \times \mathrm{CP} \%) .
$$

\section{Lipid extraction}

Milk lipid was separated following the Roese-Gottlib method (AOAC, 1995). Plasma total lipid extraction was carried out following Folch method (RodriguezEstrada et al., 1997). Fatty acids were methylated by the method described by Bernard et al. (2005).

\section{Fatty acids and CLA analysis}

Fatty acid profile (FAs) and CLA were determined for blood and milk fat samples after lipid extraction (Loor et al., 2002). Fatty acid composition was analysed using capillary GC column [Restek (Rtx-225), USA, crossbond $50 \%$-cyanopropylmethyl 50\%-phenylmethyl polysiloxane, $60 \mathrm{~m}, 0.25 \mathrm{~mm} / \mathrm{D}$, $0.25 \mathrm{um} \mathrm{df}]$ immediately after esterification and neutralization by injection $1 \mu 1$ of the hexane layer through the injection port of the GC (GC-2010, SHIMADZU). The fatty acids methyl esters (FAMEs) were identified using a chromatogram of fatty acids standard (Supelco ${ }^{\mathrm{TM}} 37$ FAMEs mix C4-C24). CLA standard (Sigma linoleic acid, conjugated methyl esters, USA) was also used and injected separately in the GC under the same conditions. The GC conditions were: column oven temperature was $70^{\circ} \mathrm{C}$ for $1 \mathrm{~min}$, increased to $200^{\circ} \mathrm{C} 20^{\circ} \mathrm{C} / \mathrm{min}$ and kept at $200^{\circ} \mathrm{C}$ for $1 \mathrm{~min}$, then increased to $220^{\circ} \mathrm{C} 1^{\circ} \mathrm{C} / \mathrm{min}$ and kept at $220^{\circ} \mathrm{C}$ for $20 \mathrm{~min}$. Injector temperature was $260^{\circ} \mathrm{C}$, detector temperature was $260^{\circ} \mathrm{C}$, flow rate $1.1 \mathrm{ml} / \mathrm{min}$ He and split ratio used was 1:25.

\section{Statistical analysis}

Values of milk yield and composition, ECM, MEV, as well as FAs and CLA were analysed using GLM procedure of SAS (2000) in a CRD repeated measures design. Model independent values included treatment (oil source and level), replicate (goat), period (time of sampling: day or week) and their interactions. Blood analysis results and daily gain of kids were analysed in a CRD arrangement. 
The analysis model includes treatment, sex, kidding, and their interactions as independent variables, while birth weight of kids and kidding weight of dams were used as covariates in the model. Least square means were separated for significances $(\mathrm{P}<0.05)$ according Fisher's protected LSD test (Steel and Torrie, 1980).

\section{RESULTS AND DISCUSSION}

\section{Milk production and composition}

Table 2 shows that total daily milk production was higher $(\mathrm{P}<0.05)$ in the control and 3\%SBO treatments and with no differences among other groups. When analysed by time of the experiment, milk production during the first 4 weeks of the experiment (up to peak production) was least $(\mathrm{P}<0.05)$ for the treatment groups with higher $(\mathrm{P}<0.05)$ production for the $\mathrm{SBO}$ groups compared with SFO groups. During the rest of the experiment (4-8 weeks), milk production was maximum $(\mathrm{P}<0.05)$ for the $3 \% \mathrm{SBO}$ group and minimum $(\mathrm{P}<0.05)$ for the $\mathrm{SFO}$ groups. However, production of the $5 \% \mathrm{SBO}$ group was similar to that of the control and 5\%SFO groups.

Table 2. Milk production and milk composition of Shami goats fed different levels of soyabean oil (SBO) and sunflower oil (SFO) in their ration

\begin{tabular}{|c|c|c|c|c|c|c|}
\hline Item & Control & $3 \% \mathrm{SBO}$ & $5 \% \mathrm{SBO}$ & $3 \% \mathrm{SFO}$ & $5 \% \mathrm{SFO}$ & SEM \\
\hline \multicolumn{7}{|l|}{ Milk production, $\mathrm{kg} / \mathrm{d}$} \\
\hline total & $2.2^{\mathrm{a}}$ & $2.2^{\mathrm{a}}$ & $1.6^{\mathrm{b}}$ & $1.3^{\mathrm{b}}$ & $1.5^{\mathrm{b}}$ & 0.18 \\
\hline $0-4$ week & $3.0^{\mathrm{a}}$ & $2.6^{\mathrm{b}}$ & $2.1^{\mathrm{c}}$ & $1.8^{\mathrm{d}}$ & $1.9^{\mathrm{d}}$ & 0.16 \\
\hline 4-8 week & $1.3^{\mathrm{b}}$ & $1.8^{\mathrm{a}}$ & $1.2^{\mathrm{b}}$ & $0.9^{\mathrm{c}}$ & $1.1^{\mathrm{bc}}$ & 0.21 \\
\hline fat, $\%$ & 5.4 & 6.0 & 5.5 & 5.2 & 5.5 & 0.25 \\
\hline$g / d$ & $116.3^{\mathrm{ab}}$ & $132.9^{\mathrm{a}}$ & $90.8^{\mathrm{bc}}$ & $69.3^{\mathrm{c}}$ & $83.3^{\mathrm{bc}}$ & 10.3 \\
\hline protein $\%$ & 4.0 & 4.0 & 3.9 & 4.0 & 4.5 & 0.14 \\
\hline$g / d$ & $85.7^{\mathrm{a}}$ & $88.4^{\mathrm{a}}$ & $63.9^{\mathrm{b}}$ & $54.0^{\mathrm{b}}$ & $68.9^{\mathrm{ab}}$ & 11.1 \\
\hline total solids, $\%$ & 12.5 & 13.4 & 12.8 & 12.7 & 14.5 & 0.74 \\
\hline Energy corrected milk, $\mathrm{kg} / \mathrm{d}^{1}$ & $1.7^{\mathrm{ab}}$ & $1.8^{\mathrm{a}}$ & $1.5^{\mathrm{bc}}$ & $1.4^{\mathrm{c}}$ & $1.5^{\mathrm{bc}}$ & 0.07 \\
\hline Milk energy value, $\mathrm{kcal} / \mathrm{kg}^{2}$ & 273.5 & 279.5 & 273.7 & 272.4 & 278.1 & 2.50 \\
\hline
\end{tabular}

Usually, fat is supplemented to the diets of lactating ruminants to increase energy density of the diet in order to increase milk production. However, the response in milk production was not always positive, but may decrease, increase, or even unchanged (Zhang et al., 2006). To our knowledge this is the first study that deals with oil supplementation to lactating Shami goats. Dietary fat addition 
had no effect on the amount of milk secreted by early and mid-lactating dairy goats (Mir et al., 1999; Bernard et al., 2005) or late lactating goats (Chilliard et al., 2003).

Milk production is directly attributed to energy intake (Loor et al., 2002). However, supplementing diets with oils rich in PUFA often results in reduced or limited feed intake and, therefore, milk production (AbuGhazaleh, 2008). The lack of response in milk production might be related mostly to dairy potential of the animals in the experiment.

Up to the expected peak level, milk production was reduced with oil supplementation and had its lowest with SFO addition. During the rest period (post peak) milk production was decreased as the level of the SBO was increased, but not with increasing level of the SFO. Bernal-Santos et al. (2003) stated that dairy cows supplemented with a fat source exhibited an apparent increase in milk yield during the early lactation period but not later during the lactation. However, Bernard et al. (2005) indicated different response to different fat sources in milk production of mid-lactating fat supplemented dairy cows.

Milk fat and protein content were not different among treatments. Meanwhile, fat yield of the $3 \% \mathrm{SBO}$ group was maximum $(\mathrm{P}<0.05)$ but not different from that of the control group (Table 2). Groups of high oil levels (5\%SBO and 5\%SFO) were not different from the control group yield or from the $3 \% \mathrm{SFO}$ group that produced the lowest $(\mathrm{P}<0.05)$ fat. However, protein yield was maximum $(\mathrm{P}<0.05)$ for the $3 \% \mathrm{SBO}$ and control groups and not different from the $5 \% \mathrm{SFO}$ group. Total solids did not differ among groups.

Chilliard et al. (2003) stated that goats, opposite to ewes and cows, do not show any fat depression after adding plant oil to high concentrate diets. On the other hand, dietary supplementation with lipids usually has a negative effect on milk protein percent but not all addition cause changes in milk protein yield as total daily production of milk protein may remains constant or increase in situations where milk yield is increased by fat supplementation (Zhang et al., 2006). According to the same reference, insufficient availability of amino acids to the mammary gland for the increased milk yield stimulated by fat supplementation maybe a major reason for this.

Energy corrected milk $(\mathrm{ECM})$ was the highest $(\mathrm{P}<0.05)$ with the $3 \% \mathrm{SBO}$ treatment but not different from the control group (Table 2), while the 3\%SFO group was the lowest $(\mathrm{P}<0.05)$ among treatments and not different from the $5 \%$ SFO and SBO diets. On the other hand, milk energy values (MEV) were not different among treatments.

The ECM is a correction of milk production for its content of fat and protein. Published literature concerning the effect of fat supplementation on ECM of goats is very scarce. To our knowledge, only AbuGhazaleh et al. (2002) reported no 
changes in ECM of dairy cows supplemented with different fat sources or their blends. Sampelayo et al. (2002a) showed no effect on energy yield in the milk due to fat supplementation by either 9 or $12 \%$ protected fat rich in PUFA which agrees with our result.

Dry matter intake, body weights, and blood metabolites

Hay intake $(\mathrm{FI})$ values $(\mathrm{kg}$ dry matter/day) were higher $(\mathrm{P}<0.05)$ for the $3 \% \mathrm{SBO}, 5 \% \mathrm{SFO}$ and control groups with no difference among other groups (Table 3). Metabolizable energy intake (MEI) was highest $(\mathrm{P}<0.05)$ for the $5 \% \mathrm{SFO}$ group while both SBO groups were less with no difference between both. MEI was least $(\mathrm{P}<0.05)$ for the control and 3\%SFO groups.

Table 3. Feed intake, body weights and blood metabolites of Shami goats fed different levels of soyabean oil (SBO) and sunflower oil (SFO) in their ration

\begin{tabular}{|c|c|c|c|c|c|c|}
\hline \multirow{2}{*}{ Item } & \multicolumn{6}{|c|}{ Diets } \\
\hline & control & $3 \% \mathrm{SBO}$ & $5 \% \mathrm{SBO}$ & $3 \%$ SFO & $5 \%$ SFO & SEM \\
\hline No. of animals & 25 & 25 & 25 & 25 & 25 & \\
\hline Feed intake, kg DM/d & $2.2^{\mathrm{a}}$ & $2.2^{\mathrm{a}}$ & $2.1^{\mathrm{b}}$ & $2.1^{\mathrm{b}}$ & $2.2^{\mathrm{a}}$ & 0.02 \\
\hline ration & 1.5 & 1.5 & 1.5 & 1.5 & 1.5 & \\
\hline hay & $0.7^{\mathrm{a}}$ & $0.7^{\mathrm{a}}$ & $0.6^{\mathrm{b}}$ & $0.6^{\mathrm{b}}$ & $0.7^{\mathrm{a}}$ & 0.02 \\
\hline $\mathrm{MEI}, \mathrm{MJ} / \mathrm{d}^{1}$ & $21.5^{\mathrm{c}}$ & $22.2^{\mathrm{b}}$ & $22.3^{\mathrm{b}}$ & $21.4^{\mathrm{c}}$ & $22.8^{\mathrm{a}}$ & 0.16 \\
\hline Feed: milk ${ }^{2}$ & $1.0^{\mathrm{a}}$ & $1.0^{\mathrm{a}}$ & $1.3^{\mathrm{b}}$ & $1.6^{\mathrm{d}}$ & $1.5^{\mathrm{c}}$ & 0.01 \\
\hline Initial body weight & 60.6 & 60.0 & 59.5 & 55.1 & 53.8 & \\
\hline Final body weight & $62.8^{a}$ & $61.8^{\mathrm{ab}}$ & $61.0^{\mathrm{ab}}$ & $56.7^{\mathrm{bc}}$ & $54.9^{\mathrm{c}}$ & 1.95 \\
\hline Body weight change & 2.2 & 1.8 & 1.5 & 1.6 & 1.1 & 0.29 \\
\hline Blood metabolites & & & & & & \\
\hline cholesterol, $\mathrm{mmol} / \mathrm{l}$ & $83.0^{\mathrm{b}}$ & $118.0^{\mathrm{a}}$ & $115.0^{\mathrm{a}}$ & $85.0^{\mathrm{b}}$ & $77.0^{\mathrm{c}}$ & 0.89 \\
\hline triglyceride, $\mathrm{mmol} / \mathrm{l}$ & $88.0^{\mathrm{a}}$ & $78.00^{\mathrm{b}}$ & $72.0^{\mathrm{c}}$ & $64.0^{\mathrm{d}}$ & $9.0^{\mathrm{b}}$ & 0.83 \\
\hline
\end{tabular}

Variation in intake is a function of variation in hay intake as intake from the concentrate was limited. Bernard et al. (2005) and AbuGhazaleh (2008) reported reduced dry matter intake (DMI) of dairy cows fed diets supplemented with PUFA rich oil. This might explain the reduced dry matter intake observed with the $5 \% \mathrm{SBO}$. DMI tended to decrease as fat level in the diet increased due to physiological regulation mechanism of feed intake in terms of increased energy density with rising level of fat the diet (Sampelayo et al., 2002b). The same reference pointed that the decrease in feed intake was also due to decreased palatability of the diets with oil supplementation.

The reason behind the increased intake observed with increased level of SFO is not clear as most of the literature reported negative effect on intake. Goats often 
have a marked preference for some feeds over other according to their palatability, while at the same time this response can be very different within the same group of animals (Sampelayo et al., 2000).

Variation in metabolizable energy intake (MEI) is a function of variation in total intake. Dietary lipid supplementation is a mean of increasing both energy intake and efficiency in early lactating ruminants (Chilliard et al., 2003). However, metabolizable energy intake of lactating goats tended to be reduced with increased fat level in the diet due to decreased feed intake at high fat levels (Sampelayo et al., 2002b). Although feed intake was decreased with increased level of the SBO, intake of ME was not affected due to increased energy content of the high oil diet.

Feed to milk ratio ( $\mathrm{kg}$ feed per $\mathrm{kg}$ milk) was different $(\mathrm{P}<0.05)$ among treatments. The ratio was best $(\mathrm{P}<0.05)$ for the both control and the $3 \% \mathrm{SBO}$ groups and poorest $(\mathrm{P}<0.05)$ for $3 \% \mathrm{SFO}$ group. Feed to milk ratio is the efficiency by which goats utilized feed for milk production.

Initial and final body weights of does are shown in Table 3. Control group had the highest $(\mathrm{P}<0.05)$ final body weight at the end of experiment with no differences from the SBO groups, while goats of the 5\%SFO group had the lowest final body weight. However, body weight change was almost similar among treatments.

Initial body weight was used as a covariate for correction in the analysis of final body weight. Chilliard et al. (2003) reported that there was no clear trend concerning the effect of fat supplementation on body weight changes in early lactation goat as body weight of these goats was either higher, lower, or unchanged by the end of the feeding period.

Serum cholesterol level $(\mathrm{mmol} / \mathrm{l})$ was maximum $(\mathrm{P}<0.05)$ in kids of the SBO groups but least $(\mathrm{P}<0.05)$ for the $5 \%$ SFO kids (Table 3$)$. Serum triglyceride was reduced following oil supplementation. Maximum $(\mathrm{P}<0.05)$ value was for the control kids and the lowest serum level was in kids of the 3\%SFO group.

Fats in the diet promote the production of lipoproteins in the intestine which is the major site of de novo cholesterol synthesis in ruminants (Espinoza et al., 1997). On the other hand, the mechanism for reducing triglycerides in blood of suckling kids of dams fed fat source rich in PUFA is due to that the PUFA reduced the lipolysis and thus led to lower plasma levels of not esterified fatty acids (NEFA) which subsequently lead to lower levels of triglycerides (Sampelayo et al., 2006).

\section{Milk FAs and CLA composition}

Fatty acids (FAs) composition of the milk is presented in Table 4. Concentration of the short chain FAs (C4-C10) did not differ among treatments except for C6:0 
fatty acid opposite to that of the medium chain FAs, C12:0 - C15:0, which was affected by the dietary treatments. No difference was observed among treatments in the concentration of $\mathrm{C} 14: 0$, while $\mathrm{C} 14: 1 \mathrm{FA}$ concentration was higher $(\mathrm{P}<0.05)$ for the $3 \% \mathrm{SFO}$ group which was not different from the $5 \% \mathrm{SBO}$ group. However, the higher $(\mathrm{P}<0.05)$ concentration of $\mathrm{C} 18: 0$ was for the control group with no difference among other treatments for the same fatty acid. C18:1 concentration was higher $(\mathrm{P}<0.05)$ for the $5 \% \mathrm{SFO}$ and lowest $(\mathrm{P}<0.05)$ for the $3 \% \mathrm{SFO}$. No differences were also observed in the concentrations of $\mathrm{C} 18: 2$ and $\mathrm{C} 18: 3$ isomers.

Table 4. Milk fatty acids and conjugated linoleic acid composition, as a percent of milk lipids, of Shami goats fed different levels of soyabean oil (SBO) and sunflower oil (SFO) in their rations

\begin{tabular}{|c|c|c|c|c|c|c|}
\hline \multirow{2}{*}{ Fatty acids } & \multicolumn{6}{|c|}{ Diets } \\
\hline & control & $3 \% \mathrm{SBO}$ & $5 \%$ SBO & $3 \%$ SFO & $5 \%$ SFO & SEM \\
\hline$\overline{\mathrm{C} 4: 0}$ & 2.3 & 2.0 & 2.4 & 2.4 & 2.7 & 0.33 \\
\hline C6:0 & $2.6^{\mathrm{b}}$ & $2.6^{\mathrm{b}}$ & $2.7^{\mathrm{b}}$ & $3.3^{\mathrm{a}}$ & $2.9^{\mathrm{ab}}$ & 0.18 \\
\hline C8:0 & 2.9 & 3.2 & 3.2 & 3.9 & 3.3 & 0.30 \\
\hline C10:0 & 9.5 & 10.1 & 9.0 & 9.5 & 9.2 & 0.31 \\
\hline C12:0 & $3.1^{\mathrm{bc}}$ & $3.4^{\mathrm{ab}}$ & $2.8^{\mathrm{c}}$ & $3.6^{\mathrm{a}}$ & $3.2^{\mathrm{b}}$ & 0.10 \\
\hline C14:0 & 8.1 & 8.5 & 7.6 & 8.3 & 8.0 & 0.25 \\
\hline C14:1 & $0.1^{\mathrm{b}}$ & $0.2^{\mathrm{b}}$ & $0.3^{\mathrm{ab}}$ & $0.5^{\mathrm{a}}$ & $0.1^{\mathrm{b}}$ & 0.07 \\
\hline C15:0 & $0.6^{\mathrm{b}}$ & $0.7^{\mathrm{ab}}$ & $0.7^{\mathrm{ab}}$ & $0.8^{\mathrm{a}}$ & $0.5^{\mathrm{b}}$ & 0.08 \\
\hline C16:0 & 26.8 & 27.9 & 26.7 & 24.8 & 26.4 & 0.73 \\
\hline C16:1 & 0.6 & 0.7 & 0.7 & 0.7 & 0.6 & 0.06 \\
\hline C17:0 & $0.7^{\mathrm{b}}$ & $0.6^{\mathrm{b}}$ & $0.6^{\mathrm{b}}$ & $0.8^{\mathrm{a}}$ & $0.6^{\mathrm{b}}$ & 0.04 \\
\hline C17:1 & 0.4 & 0.5 & 0.4 & 0.5 & 0.3 & 0.07 \\
\hline C18:0 & $11.8^{\mathrm{a}}$ & $9.9^{b}$ & $10.3^{\mathrm{b}}$ & $10.1^{\mathrm{b}}$ & $10.6^{\mathrm{b}}$ & 0.37 \\
\hline $\mathrm{C} 18: 1 \mathrm{n} 9 \mathrm{c}$ & $25.6^{\mathrm{ab}}$ & $24.5^{\mathrm{bc}}$ & $25.8^{\mathrm{ab}}$ & $23.6^{\mathrm{c}}$ & $27.1^{\mathrm{a}}$ & 0.70 \\
\hline $\mathrm{C} 18: 2 \mathrm{n} 6 \mathrm{t}$ & 0.4 & 0.5 & 0.7 & 0.7 & 0.4 & 0.09 \\
\hline $\mathrm{C} 18: 2 \mathrm{n} 6 \mathrm{c}$ & 1.9 & 1.9 & 2.3 & 2.2 & 1.9 & 0.09 \\
\hline C18:3n6 & 0.22 & 0.31 & 0.38 & 0.50 & 0.1 & 0.09 \\
\hline C18:3n3 & 1.2 & 0.7 & 0.9 & 0.79 & 0.5 & 0.28 \\
\hline C20:0 & $0.2^{\mathrm{b}}$ & $0.4^{\mathrm{ab}}$ & $0.5^{\mathrm{a}}$ & $0.5^{\mathrm{ab}}$ & $0.2^{\mathrm{b}}$ & 0.10 \\
\hline \multicolumn{7}{|c|}{ Conjugated linoleic acid (CLA) } \\
\hline total & $0.8^{\mathrm{b}}$ & $1.2^{\mathrm{a}}$ & $1.5^{\mathrm{a}}$ & $1.5^{\mathrm{a}}$ & $1.0^{\mathrm{b}}$ & 0.16 \\
\hline$c 9, t 11$ & $0.6^{\mathrm{c}}$ & $0.9^{\mathrm{b}}$ & $1.2^{\mathrm{a}}$ & $1.0^{\mathrm{ab}}$ & $0.9^{\mathrm{ab}}$ & 0.11 \\
\hline$t 10, c 12$ & 0.3 & 0.3 & 0.3 & 0.5 & 0.1 & 0.08 \\
\hline UFA $^{1}$ & 31.4 & 30.6 & 33.3 & 31.4 & 32.3 & 0.76 \\
\hline$\underline{\mathrm{UFA} / \mathrm{SFA}^{2}}$ & 2.3 & 2.3 & 2.0 & 2.2 & 2.2 & 0.08 \\
\hline
\end{tabular}

a,b,c means with different superscripts within the same raw are different $(\mathrm{P}<0.05)$

${ }^{1}$ UFA - unsaturated fatty acids; ${ }^{2}$ SFA - saturated fatty acids

Total CLA concentration was maximum $(\mathrm{P}<0.05)$ for the $3 \% \mathrm{SBO}, 5 \% \mathrm{SBO}$ and $3 \% \mathrm{SFO}$ groups. Meanwhile, cis-CLA was maximum $(\mathrm{P}<0.05)$ in milk of goats in the 5\%SFO groups. The trans-CLA did not differ among treatments. Unsaturated fatty acids (UFA) and the ratio of PUFA/SFA in milk fat were similar among treatments. 
Milk fatty acid composition is linked to intrinsic (breed, genotype, lactation) or extrinsic factors (Chilliard and Ferly, 2004). Nutrition, therefore, constitutes a natural way to modulate milk fatty acid composition (Chilliard et al., 2003).

In line with present results, short chain FA concentrations (C4:0-C10:0) are classically either unchanged or only slightly reduced by increased lipid supplementation in the diet or body lipid mobilization. This maybe probably explained by the fact that those fatty acids are partly synthesized by metabolic pathways not dependent on lipid synthesis in the body (Chilliard and Ferlay, 2004).

Decreased concentration of C14:0 and C14:1 fatty acids might be due to reduction of acetyl-CoA carboxylase activity as the mammary gland increases uptake and preferential incorporation of exogenous long chain FAs derived from the diet or adipose tissue into milk fat (Loor et al., 2002). Similar results for stearic acid (C18:0) were obtained with early lactating dairy cows supplemented with SBO or canola oil (Loor and Herbein, 2003). Feeding unprotected oils increases C18:0 and C18:1 at the expense of the short and medium-chain FAs, leading to both total and partial hydrogenation of unsaturated FA taking place in the rumen and probably a large extent to unidentified trans isomers of C18:1 (Chilliard et al., 2003). This is due to the hydrogenation of the poluyunsaturated FAs with 18 carbon atoms to produce $\mathrm{C} 18: 0$ and trans $\mathrm{C} 18: 1$ acids that inhibitors of de novo synthesis (Sampelayo et al., 2006).

However, the failure to cause an increase in the proportion of C18:0 is most likely due to the activity of the $\Delta 9$-desaturase enzyme which converts the additional C18:0 derived from oil supplementation into C18:1 within the mammary gland (Zhang et al., 2006). Moreover, oil supplements might have caused more incomplete biohydrogenation of fatty acids in the rumen possibly by altering the rumen microbial ecosystem (AbuGazaleh et al., 2002).

The reasons for these differences in dairy performance response to fat supplementation between ruminant species are not easy to identify, as fewer trials and less information are available for ewes and goats than for dairy cows (Chilliard et al., 2003). The difference may be linked to complex digestive and metabolic interactions between the basal diet, fats supplementation, and animal characteristics such as species, breed, lactation stage and milk potential (Chilliard et al., 2003).

Cis-9, trans-11 CLA is the most common CLA isomer, although, the presense of other CLA isomers and their probaply concentrations vary according to rumen condition (Matsushita et al., 2007). Results of the cis-9, trans-11 CLA agrees with AbuGazaleh et al. (2002) who found that feeding SBO to lactating dairy cows has increased milk cis-9, trans-11 CLA, and Zhang et al. (2006) who revealed that ewes fed SF seed increased total and cis-9, trans-11 CLA concentration in their milk. Mir et al. (1999) suggested that the reason behind this increase in CLA milk 
concentration was due to the precursors of CLA, C18:2 and C18:3, found in oil of C18:2 which present in higher concentration in SBO than in SFO (Zhang et al., 2006; Matsushita et al., 2007). The amount of CLA and type of CLA isomers in ruminants' milk fat produced as a result of feeding supplemental fat varies to a large extent depending on the ruminal conditions and the availability of the oils to the rumen microbes (Loor and Herbein, 2003), as well as to animal characteristics such as species, breed, lactation stage and genetic potential (Chilliard et al., 2003).

\section{Kids'performance}

Birth and weaning weights for kids born to female goats in the experiment are shown in Table 5. No differences were observed among weaning weights with a slight effect for sex of kid. Likewise, treatment $\times$ sex interaction was also not significant. Average daily gain was also similar among treatments in the experiment.

Table 5. Weaning weight, weight gain of kids from Shami goats fed different levels of soyabean oil (SBO) and sunflower oil (SFO) in their rations

\begin{tabular}{lcccccc}
\hline \multirow{2}{*}{ Item } & \multicolumn{7}{c}{ Diets } \\
\cline { 2 - 7 } & control & $3 \%$ SBO & $5 \%$ SBO & $3 \%$ SFO & $5 \%$ SFO & SEM \\
\hline Birth weight, kg & 3.9 & 3.8 & 3.9 & 3.5 & 3.5 & \\
Weaning weight, $\mathrm{kg}$ & 15.6 & 16.7 & 14.9 & 15.5 & 15.5 & 0.63 \\
$\quad$ male & 16.6 & 17.0 & 15.9 & 16.7 & 14.7 & 0.77 \\
$\quad$ female & 14.6 & 16.4 & 13.9 & 14.2 & 16.3 & 0.99 \\
Average daily gain, $\mathrm{kg}$ & 0.2 & 0.2 & 0.2 & 0.2 & 0.2 & 0.20 \\
$\quad$ male & 0.2 & 0.2 & 0.2 & 0.2 & 0.2 & 0.18 \\
$\quad$ female & 0.2 & 0.2 & 0.2 & 0.2 & 0.2 & 0.21 \\
Milk conversion ratio $^{1}$ & $6.0^{\mathrm{c}}$ & $4.8^{\mathrm{bc}}$ & $4.0^{\mathrm{ab}}$ & $3.4^{\mathrm{a}}$ & $3.5^{\mathrm{a}}$ & 0.45 \\
$\quad$ male $_{\text {female }}$ & $6.8^{\mathrm{c}}$ & $5.3^{\mathrm{bc}}$ & $3.9^{\mathrm{ab}}$ & $2.7^{\mathrm{a}}$ & $3.8^{\mathrm{a}}$ & 0.54 \\
\hline
\end{tabular}

a;b,c,d means with different superscripts within the same raw are different $(\mathrm{P}<0.05)$

${ }^{1}$ milk conversion ratio: milk consumed (suckeled) during $60 \mathrm{~d}$ : daily body weight gain, $\mathrm{kg} / \mathrm{kg}$

Milk conversion ratio $(\mathrm{MCR})$ was better $(\mathrm{P}<0.05)$ for both $\mathrm{SFO}$ groups and worst for the control treatment except that of the 3\%SBO treatment. Male kids have the same effect on MCR with a better $(\mathrm{P}<0.05)$ value for the SFO groups and the control group had the worst $(\mathrm{P}<0.05) \mathrm{MCR}$ but not different from the $3 \% \mathrm{SBO}$ group.

Milk conversion ratio (MCR) reflects the efficiency of converting suckled milk into body weight during the $60 \mathrm{~d}$ suckling period and was expressed as milk consumed during this period to the daily body weight gain, $\mathrm{kg} / \mathrm{kg}$. Although weaning weights were similar but better MCR would mostly be a result of the lower average birth weights of kids in those groups. 


\section{Kids'blood FAs and CLA composition}

Fatty acid profile and CLA of bloods for kids from dams in different groups of the study is shown in Table 6. $\mathrm{C} 4: 0$ was reduced $(\mathrm{P}<0.05)$ and $\mathrm{C} 6: 0$ was increased $(\mathrm{P}<0.05)$ with oil supplementation. $\mathrm{C} 14: 0$ was increased with oil supplementation as the $3 \%$ oil supplemented diets $(\mathrm{SFO}$ and $\mathrm{SBO})$ were highest $(\mathrm{P}<0.05)$ among other groups while the $5 \%$ groups $(\mathrm{SBO}$ and $\mathrm{SFO})$ had less $(\mathrm{P}<0.05)$ values. C14:1 FA was also increased following oil treatment with both SBO groups and the $3 \%$ SFO group having maximum $(\mathrm{P}<0.05)$ values.

Table 6. Blood fatty acids and CLA composition of blood of kids from Shami goat fed different levels of soyabean oil (SBO) and sunflower oil (SFO) in their rations

\begin{tabular}{lcccccc}
\hline \multirow{2}{*}{ Fatty acids } & \multicolumn{5}{c}{ Diets } \\
\cline { 2 - 7 } C4:0 & control & $3 \%$ SBO & $5 \%$ SBO & $3 \%$ SFO & $5 \%$ SFO & SEM \\
C6:0 & $2.2^{\mathrm{a}}$ & $0.2^{\mathrm{b}}$ & $0.2^{\mathrm{b}}$ & $0.4^{\mathrm{b}}$ & $0.9^{\mathrm{b}}$ & 0.54 \\
C8:0 & $0.01^{\mathrm{b}}$ & $2.3^{\mathrm{a}}$ & $1.5^{\mathrm{a}}$ & $2.4^{\mathrm{a}}$ & $2.0^{\mathrm{a}}$ & 0.81 \\
C10:0 & $0.7^{\mathrm{c}}$ & $4.4^{\mathrm{b}}$ & $3.1^{\mathrm{b}}$ & $6.1^{\mathrm{a}}$ & $4.2^{\mathrm{b}}$ & 1.80 \\
C12:0 & $0.2^{\mathrm{c}}$ & $2.4^{\mathrm{a}}$ & $1.0^{\mathrm{bc}}$ & $2.4^{\mathrm{a}}$ & $1.9^{\mathrm{ab}}$ & 0.57 \\
C14:0 & $0.2^{\mathrm{c}}$ & $2.6^{\mathrm{a}}$ & $1.5^{\mathrm{b}}$ & $1.0^{\mathrm{bc}}$ & $0.7^{\mathrm{c}}$ & 0.45 \\
C14:1 & $1.6^{\mathrm{c}}$ & $2.9^{\mathrm{a}}$ & $2.0^{\mathrm{bc}}$ & $3.4^{\mathrm{a}}$ & $2.1^{\mathrm{b}}$ & 0.16 \\
C15:0 & $0.3^{\mathrm{c}}$ & $3.3^{\mathrm{a}}$ & $3.2^{\mathrm{a}}$ & $2.8^{\mathrm{ab}}$ & $1.6^{\mathrm{bc}}$ & 0.25 \\
C16:0 & $0.2^{\mathrm{b}}$ & $2.3^{\mathrm{a}}$ & $1.8^{\mathrm{a}}$ & $18^{\mathrm{a}}$ & $0.8^{\mathrm{b}}$ & 0.59 \\
C16:1 & $22.4^{\mathrm{a}}$ & $14.7^{\mathrm{b}}$ & $13.3^{\mathrm{b}}$ & $14.3^{\mathrm{b}}$ & $13.4^{\mathrm{b}}$ & 2.39 \\
C17:0 & $0.3^{\mathrm{b}}$ & $1.2^{\mathrm{ab}}$ & $1.9^{\mathrm{a}}$ & $1.6^{\mathrm{ab}}$ & $0.9^{\mathrm{b}}$ & 0.57 \\
C17:1 & 0.9 & 1.0 & 0.9 & 1.2 & 0.8 & 0.12 \\
C18:0 & $0.8^{\mathrm{c}}$ & $2.1^{\mathrm{ab}}$ & $2.3^{\mathrm{a}}$ & $3.0^{\mathrm{a}}$ & $1.6^{\mathrm{b}}$ & 0.49 \\
C18:1n9c & $19.2^{\mathrm{a}}$ & $12.6^{\mathrm{b}}$ & $12.6^{\mathrm{b}}$ & $11.7^{\mathrm{b}}$ & $13.3^{\mathrm{b}}$ & 1.94 \\
C18:2n6t & $20.7^{\mathrm{a}}$ & $12.9^{\mathrm{b}}$ & $12.5^{\mathrm{b}}$ & $13.0^{\mathrm{b}}$ & $15.8^{\mathrm{ab}}$ & 2.04 \\
C18:2n6c & 1.2 & 1.5 & 1.7 & 2.3 & 2.3 & 0.57 \\
C18:3n6 & $18.0^{\mathrm{a}}$ & $10.7^{\mathrm{b}}$ & $14.0^{\mathrm{b}}$ & $9.0^{\mathrm{b}}$ & $11.7^{\mathrm{b}}$ & 1.57 \\
C18:3n3 & $2.0^{\mathrm{b}}$ & $2.2^{\mathrm{b}}$ & $4.5^{\mathrm{a}}$ & $2.1^{\mathrm{b}}$ & $2.6^{\mathrm{ab}}$ & 0.34 \\
C20:0 & 3.4 & 3.7 & 5.0 & 4.2 & 6.2 & 1.44 \\
Conjugated linoleic acid (CLA) & & & & & & \\
total & 2.2 & 4.2 & 4.9 & 4.9 & 3.0 & 1.60 \\
cis-9, trans-11 & $3.5^{\mathrm{d}}$ & $9.0^{\mathrm{c}}$ & $10.1^{\mathrm{b}}$ & $8.8^{\mathrm{c}}$ & $11.3^{\mathrm{a}}$ & 0.19 \\
trans-10, cis-12 & $2.2^{\mathrm{b}}$ & $4.5^{\mathrm{a}}$ & $4.7^{\mathrm{a}}$ & $4.5^{\mathrm{a}}$ & $4.5^{\mathrm{a}}$ & 0.40 \\
UFA & 1.3 & 4.5 & 5.4 & 4.3 & $6.7^{1}$ & 1.09 \\
UFA/SFA & $50.0^{\mathrm{b}}$ & $46.5^{\mathrm{b}}$ & $55.1^{\mathrm{a}}$ & $46.7^{\mathrm{b}}$ & $53.9^{\mathrm{a}}$ & 1.04 \\
\hline
\end{tabular}

${ }_{a, b, c, d}$ means with different superscripts within the same raw are different $(\mathrm{P}<0.05)$

${ }^{1} \mathrm{UFA}$ - unsaturated fatty acids; ${ }^{2} \mathrm{SFA}$ - saturated fatty acids

C18:0 was lowest $(\mathrm{P}<0.05)$ when oil diets were used with no differences observed among oil supplemented groups. $\mathrm{C} 18: 1 \mathrm{n} 9 \mathrm{c}$ was also higher $(\mathrm{P}<0.05)$ for the control and the 5\% SFO groups. No differences were observed in the concentrations of $\mathrm{C} 18: 2 \mathrm{n} 6 \mathrm{t}$ and $\mathrm{C} 18: 3 \mathrm{n} 3$. The concentration of linoleic acid $(\mathrm{C} 18: 2 \mathrm{n} 6 \mathrm{c})$ was reduced $(\mathrm{P}<0.05)$ in oil supplementing diets. $\mathrm{C} 20: 0$ was similar 
among treatments, however, unsaturated fatty acids were increased $(\mathrm{P}<0.05)$ by increasing level of oil supplemented irrespective of the oil source.

Total CLA concentration reached maximum $(\mathrm{P}<0.05)$ in the $5 \% \mathrm{SFO}$ group followed $(\mathrm{P}<0.05)$ by the $5 \% \mathrm{SBO}$ group. Groups supplemented with low oil level (both oils) were intermediate $(\mathrm{P}<0.05)$ while the control had the lowest $(\mathrm{P}<0.05)$ concentration. Cis-9, trans-11 CLA concentrations was highest $(\mathrm{P}<0.05)$ in the oil treated groups regardless of the oil source or level. Other CLA isomers (trans10,cis-12) were similar among groups.

To our knowledge, no data is available with regard to the full fatty acid profile in the blood serum of goat kids. However, these results of the serum FAs profile are a reflection of the FA profile of their dams' milk. Sampelayo et al. (2006) found that when supplementing the diets of dam goats with a fat source, the FAs composition in the tissue fat of suckling kids was almost the same as that of their dams' milk FAs composition.

Again, the concentrations of the short chain FAs (C4:0-C10:0) are classically either unchanged or only slightly reduced by increased lipid supplementation in the diet or body lipid mobilization due to that those fatty acids are partly synthesized by metabolic pathways not dependent on lipid synthesis in the body (Chilliard and Ferlay, 2004). In the present case, except for the C4:0 FA, other short chain FAs were increased following oil supplementation regardless of the oil source or level. This would most probably be due to the metabolism of milk fats in the rumen of these kids that raise the concentration of such FAs.

The concentration of medium chain FAs (C15-C17) was increased in the blood serum of kids from the oil supplemented group regardless of oils level or source. This would mostly be due to that kids were suckling dams fed oil supplemented diets which resulted in accumulation of fat metabolites in the blood of those kids.

Total and cis-9,trans-11 CLA in the blood, like that of milk, were affected by oil treatment. The increased CLA concentration in muscle tissues of kids was accompanied by increased CLA in the milk of their dams (Sampelayo et al., 2006). The higher result of CLA concentration in blood FAs might be due to that the diet being high in linoleic oil would lead to increased CLA accumulation as a result of increased ruminal CLA production (Chilliard et al., 2003). The increase in UFA concentration reflected incomplete rumen biohydrogenation and consequently a high level available for absorption and appeared in the blood (Demirel et al., 2004). This is expected due to the low age at which blood samples were taken from those kids.

Therefore, supplementing early lactating Shami goats' diets with either SBO or SFO in 2 concentrations ( 3 and $5 \%$ ) of grain intake did not improve milk production, percentages of milk contents or yield of milk protein. However, yield 
of milk fat seems to be better for SBO treatments over SFO treatment but without overall improvement. Both oils did not affect weaning weights of kids born to these goats but improved milk conversion ratio. Total and cis-9,trans-11 CLA were increased with both oils except 5\%SFO. Blood serum FAs profile of kids was altered with oil supplementation without a clear trend; CLA either total or cis-9 form increased with oil supplementation with higher concentration to $5 \% \mathrm{SFO}$.

\section{CONCLUSIONS}

These result demonstrate a considerable scope in manipulating the fatty acid (FA) composition of goat milk with no much effect of the $5 \%$ oil supplementation due to no further increase in milk beneficial FA(CLA). Treatment or supplementation with soyabean oil seems be more efficient than sunflower oil, however, further studies are needed to study the effect of such supplements on kids blood metabolites and FA profile and growth.

\section{REFERENCES}

AbuGhazaleh A., 2008. Effect of fish oil and sunflower oil supplementation on milk conjugated linoleic acid content for grazing dairy cows. Anim. Feed Sci. Tech. 141, 220-232

AbuGhazaleh A., Schingoethe D., Hippen A., Kalscheur K., Whitlock L., 2002. Fatty acid profiles of milk and rumen digesta from cows fed fish oil, extruded soyabeans or their blend. J. Dairy Sci. $85,2266-2276$

AOAC, 1995. Association of Official Analytical Chemists, Official Methods of Analysis. $16^{\text {th }}$ Edition. Arlington, VA

Baldi A., Modina S., Cheli F., Gandolfi F., Pinotti L., Scesi L., Fantuz F., Dell’Orto V., 2002. Bovine somatotropin administration to dairy goats in late lactation: Effects on mammary gland function, composition and morphology. J. Dairy Sci. 85, 1093-1102

Bernal-Santos G., Perfield J., Barbano I., Bauman D., Overton T., 2003. Production responses of dietary caws to dietary supplementation with conjugated linoleic acid (CLA) during the transition period and early location. J. Dairy Sci. 86, 3218-3228

Bernard L., Rouel J., Leroux C., Ferlay A., Faulconnier Y., 2005. Mammary lipid metabolism and milk fatty acid secretion in alpine goats fed vegetable lipids. J. Dairy Sci. 88, 1478-1489

Chilliard Y., Ferlay A., 2004. Dietary lipids and forages interactions on cow and goat milk fatty acid composition and sensory properties. Reprod. Nutr. Develop. 44, 467-492

Chilliard Y., Ferlay A., Rouel J., Lamberet G., 2003. A review of nutritional and physiological factors affecting goat milk lipid synthesis and lipolysis. J. Dairy Sci. 86, 1751-1770

Demirel G., Wood J., Enser M., 2004. Conjugated linoleic acid content of the lamb muscle and lever fed different supplements. Small Ruminant Res. 53, 23-28

Espinoza J., Ramirez-Godinez J., Simental S., Jimenez J., Ramirez R., Palacios A., Lun R., 1997. Effects of calcium soaps of fatty acids on serum hormones and lipid metabolism in pelibuey ewes. Small Ruminant Res. 26, 61-68 
Georing H.K., Van Soest P.J., 1970. Forage Fiber Analysis. Agriculture Handbook No. 379. Agriculture Research Service USDA. Washington, DC

Loor J., Herbein J., 2003. Dietary canola or soybean oil with two levels of conjugated linoleic acids (CLA) alter profiles of 18:1 and 18:2 isomers in blood plasma and milk fat from dairy cows. Anim. Feed Sci. Tech. 103, 63-83

Loor J., Herbein J., Jenkins T., 2002. Nutrient digestion, biohydrogenation and fatty acid profiles in blood plasma and milk fat from lactating Holstein cows fed canola oil or canolamide. Anim. Feed Sci. Tech. 97, 65-82

Matsushita M., Tazinafo N., Padre R., Oliveira C., Souza N., Visentainer J., Macedo F., Ribas N., 2007. Fatty acid profile of milk from Saanen goats fed a diet enriched with three vegetable oils. Small Ruminant Res. 72, 127-143

Mir Z., Goonewardene L., Okine E., Jaegar S., Scheer H., 1999. Effect of feeding canola oil on constituents, conjugated linolic acid (CLA) and long chain fatty acids in goats' milk. Small Ruminant Res. 33, 137-143

NRC, 1985. Nutrient Requirements of Goat. $6^{\text {th }}$ revised Edition. National Research Council. Washington, DC

Rodriguez-Estrada M.T., Penazzi G., Caboni M.F., Bertacco G., Lercker G., 1997. Effect of different cocking methods on some lipid and protein components of hamburgers. Meat Sci. 44, 1-11

Sampelayo M., Alonso J., Moron D., Perez L., Boza J., 2000. Production of healthier goat milk. Use of a concentrate supplemented with a "protected fat" rich in PUFA. J. Physiol. Biochem. 56, 231-236

Sampelayo M., Fernandez J., Ramos E., Hermoso R., Gill Extremera F., Boza J., 2006. Effect of providing a polyunsaturated fatty acid-rich protected fat to lactating goats on growth and body composition of suckling goat kids. Anim. Sci. 82, 337-344

Sampelayo M., Perez L., Alonso J., Amigo L., Boza J., 2002b. Effect of concentrates with different contents of protected fat rich in PUFAs on a performance of lactating granadina goats part II. Milk production and composition. Small Ruminant Res. 43, 141-148

Sampelayo M., Perez L., Alonso J., Extremera F., Boza J., 2002a. Effect of concentrates with different contents of protected fat rich in PUFAs on a performance of lactating granadina goats 1 . feed intake, nutrient digestibility, $\mathrm{N}$ and energy utilization for milk production. Small Ruminant Res. 43, 133-139

SAS, 2000. SAS Statistically User's Guide, Version 7. SAS Institute Inc. Cary, NC

Steel G.D.R., Torrie H.J., 1980. Principles and Procedures of Statistics. $2^{\text {nd }}$ Edition. McGrow-Hill, New York

Zhang R., Mustafa A., Zhao X., 2006. Effect of feeding oilseeds rich in linoleic and linolenic fatty acids to lactating ewes on cheese yield and on fatty acid composition of milk and cheese. Anim. Feed Sci. Tech. 127, 220-233 